\title{
Stress Resistance and Adaptation of the Aquatic Invasive Species Tubastraea Coccinea (Lesson, 1829) to Climate Change and Ocean Acidification
}

\author{
Kevin B. Strychar ${ }^{1}{ }^{*}$, Briana Hauff-Salas ${ }^{2}$, Joshua A. Haslun ${ }^{3}$, Jessica DeBoer ${ }^{4}$, Katherine Cryer ${ }^{5}$, Scott Keith ${ }^{6}$ \\ and Sam Wooten ${ }^{7}$
}

check for updates

Citation: Strychar, K.B.; Hauff-Salas, B.; Haslun, J.A.; DeBoer, J.; Cryer, K.; Keith, S.; Wooten, S. Stress Resistance and Adaptation of the Aquatic Invasive Species Tubastraea Coccinea (Lesson, 1829) to Climate Change and Ocean Acidification. Water 2021, 13, 3645. https://doi.org/10.3390/ w13243645

Academic Editor: Lidong Shen

Received: 24 November 2021 Accepted: 13 December 2021 Published: 18 December 2021

Publisher's Note: MDPI stays neutral with regard to jurisdictional claims in published maps and institutional affiliations.

Copyright: (C) 2021 by the authors Licensee MDPI, Basel, Switzerland. This article is an open access article distributed under the terms and conditions of the Creative Commons Attribution (CC BY) license (https:/ / creativecommons.org/licenses/by/ $4.0 /)$.
1 Annis Water Resources Institute, Grand Valley State University, Muskegon, MI 49441, USA

2 Department of Mathematics and Science, Our Lady of the Lake University, San Antonio, TX 78207, USA; bhsalas@ollusa.edu

3 Lux Research Inc., Emerging Ecosystems in Agrifood and Health, 100 Franklin Street, 8th Floor, Boston, MA 02110, USA; Joshua.Haslun@luxresearchinc.com

4 Biology Department, Augustana College, Sioux Falls, SD 57197, USA; jhdeboer08@ole.augie.edu

5 College of Natural Sciences and Mathematics, Dallas Baptist University, Dallas, TX 75211, USA; CryerK@dbu.edu

6 Department of Biology, Kenyon College, Gambier, OH 43022, USA; SKeith@andrew.cmu.edu

7 Department of Science and Mathematics, Furman University, Greenville, SC 29613, USA; sam.wooten@furman.edu

* Correspondence: strychak@gvsu.edu; Tel.: +1-616-331-8796

\begin{abstract}
A great number of studies published on long-term ocean warming and increased acidification have forecasted changes in regional biodiversity preempted by aquatic invasive species (AIS). The present paper is focused on invasive Tubastraea coccinea (TC), an azooxanthellate AIS coral thriving in regions of the Gulf of Mexico, which has shown an ability to invade altered habitats, including endemic Indo-Pacific T. coccinea (TCP) populations. To determine if invasive TC are more stress resistant than endemic Indo-Pacific T. coccinea (TCP), authors measured tissue loss and heat shock protein 70 (HSP70) expression, using a full factorial design, post exposure to changes in $\mathrm{pH}$ (7.5 and 8.1) and heat stress $\left(31^{\circ} \mathrm{C}\right.$ and $\left.34^{\circ} \mathrm{C}\right)$. Overall, the mean time required for TCP to reach $50 \%$ tissue loss (LD50) was less than observed for TC by a factor of $0.45(p<0.0003)$. Increasing temperature was found to be a significant main effect $(p=0.004)$, decreasing the LD50 by a factor of 0.58 . Increasing acidity to $\mathrm{pH} 7.5$ from 8.1 did not change the sensitivity of TC to temperature; however, TCP displayed increased sensitivity at $31^{\circ} \mathrm{C}$. Increases in the relative density of HSP70 (TC) were seen at all treatment levels. Hence, TC appears more robust compared to TCP and may emerge as a new dominant coral displacing endemic populations as a consequence of climate change.
\end{abstract}

Keywords: climate change; ocean acidification; coral bleaching; invasive species; Tubastraea coccinea; HSP70

\section{Introduction}

Under current global climate change projections where both marine and freshwater habitats are expected to continue to change, i.e., become warmer and more acidic [1], invasive species are anticipated to continue to increase in drastic numbers, altering environments on a large scale. Sammarco and Strychar [2] suggested as endemic habitats warm to unbearable temperatures, species will be forced to move toward the poles. Complications in the marine environment stemming from increased atmospheric $\mathrm{CO}_{2}$, including increases in sea surface temperatures and ocean acidification, will change conditions such that endemic organisms will need to adapt or perish under competition from more fit and/or less predated individuals $[3,4]$. With the effect of increases in sea surface temperatures already observed on coral reefs [5] as well as the impacts of acidification on coral calcification and metabolism [6-8], the implications of an invasion by a successful benthic colonizer on reef 
diversity and complexity could be severe. Here, we discuss the ahermatypic, azooxanthellae (lacking an algal symbiont) coral Tubastraea coccinea as an invasive species in the Caribbean and Gulf of Mexico [9-13] and discuss its potential resilience to climate change. Introduced to Curaçao from the Pacific in 1943 [14], Tubastraea coccinea [15] (Cnidaria, Anthozoa, Scleractinia, Dendrophylliidae) has proved to be a successful colonizer of available habitat through its early reproductive age $[16,17]$, fast growth and budding abilities [18,19], domination of habitats [20,21], development and larval competence [22], microbial mucus surface layer [23], and novel growth strategies [18]. Commonly called sun coral, orange cup coral, and/or golden flower coral, this species experiences little to no predation in the Caribbean and Gulf of Mexico [24,25] albeit Epidendrium billeeanum (gastropod snail) has been reported to feed on this species in the eastern Pacific [26,27]. Commonly called the golden wentletrap or yellow sea snail, E. billeeanum to our knowledge has not yet been observed in the United States but has been observed in the Gulf of California [28]. As of recent, T. coccinea has been identified in Brazil [29-32], Florida and the Gulf of Mexico [33,34], and the Southwestern Atlantic [35,36]. Although its specific method of invasion remains a mystery, it is likely spreading via ballast water discharge, biofouling associated with marine traffic, and trading as an ornamental aquarium species. However, as early as 1985, Wellington and Trench [37] described Tubastraea spp. as unusually persistent in open reef habitats, especially given that it was non-symbiotic, and such coral tend to be more cryptic and less successful in competing for spatial habitat. Lages et al. [38] demonstrated the ability of $T$. coccinea to modify shallow tropical rocky shore communities in the southwest Atlantic via range expansion and habitation of space normally occupied by native species. Figueroa et al. $[13,39]$ reported that range expansion is "facilitated" by different clades remaining relatively "ordinary" in appearance. Sammarco [40] and Kolian and Sammarco [41] suggest that its presence on oil platforms begins "inconspicuously", but it aggressively overtakes a habitat where it has no known diseases and predators, and endemic species are quickly overrun. As no fossils of $T$. coccinea have been found in the Caribbean [42], it is clear that $T$. coccinea is an invasive colonizer that negatively affects indigenous benthic organisms in the Western Atlantic.

Over the past few years, several studies have ensued regarding Tubastraea spp., such as secondary dispersion [43], microbiome [44], life history [45], pharmacological activity [46,47], genome [48], and clonality [43]. Minimal work, however, has been done on T. coccinea in order to ascertain whether this species "bleaches" like so many other stony coral species and whether it has the potential ability to endure the effects of climate change. Here, we define bleaching as the loss of symbionts, i.e., Symbiodiniaceae [49], associated pigments, loss of tissue, and/or coloration resulting in the pale/white coral skeleton being exposed [50]. Hayes and King [51] showed that T. coccinea may produce a molecular response to thermal stress. Hayes and King [51] suggested that in response to increasing temperatures, heat shock protein 70 (HSP70) is upregulated in T. coccinea to a maximum expression at one-hour post exposure and subsequently returned to constitutive expression. The induction of HSP70 is frequently studied in temperature sensitive organisms, such as coral, and has been correlated with organismal thermotolerance. Similarly, there may be few if any known studies of ocean acidification on Tubastraea spp. Knowing that the consequence of acidification is to drive communities toward non-calcified habitats [52], a change in ocean acidity would likely reduce skeletal density in this species [53]. Why this species is a better colonizer in the West as opposed to its congener in the Indo-Pacific is also unknown.

Here, we show that invasive T. coccinea are more stress resistant to increases in temperature and acidity than their Indo-Pacific conspecifics. We also show that synergistic effects of $\mathrm{pH}$ and temperature on invasive T. coccinea are minimal. These results demonstrate the probability of T. coccinea displacing endemic populations of coral in the Western Atlantic leading to large changes in these reef ecosystems. 


\section{Materials and Methods}

\subsection{Materials, Study Organism, Collection, and Preparation}

In this study, our focus was to compare invasive versus endemic Tubastraea coccinea coral to help determine if "recently settled" invasives (i.e., those living in the Gulf of Mexico) were better adapted than endemic species (i.e., wild congeners from the Indo Pacific). Invasive Tubastraea coccinea (TC) samples were collected from two offshore oil platforms (MC-109-A and AC-SP-87-D) in the Gulf of Mexico at depths between 10-20 m $(n=12)$. Divers using SCUBA (Self Contained Underwater Breathing Apparatus) collected coral using a rock saw, hammer, and/or chisel by removing polyps at their base. Coral were then placed in collection bags and transported to the surface, at which point all samples were brought aboard our research vessel (M/V Fling, Gulf Diving Inc., Freeport, TX, USA), and all fragments were rinsed with site derived seawater and placed in coolers filled with site derived seawater. Fifty percent of the seawater within the coolers was flushed every $6 \mathrm{~h}$ until transport to the shore occurred; this was done to help reduce any stress and metabolite build-up. Aboard the research vessel, we also collected $\sim 750 \mathrm{~L}$ of site derived seawater, maintaining that water at the same temperature the coral were collected. The $750 \mathrm{~L}$ of water was used to flush the coral during transport from the research vessel at shore to the research laboratory. At the research laboratory, all coral were placed in holding tanks both to allow the coral to acclimate and depurate; corals were held for approximately 7 days at temperatures similar to the collection site. Rearing conditions during the acclimation period consisted of water quality and chemistry monitoring. Nitrate, phosphate, calcium, and carbonate were monitored using saltwater liquid master test kits (API Pharmaceuticals ${ }^{\circledR}$, Washington, DC, USA). Any results deviating from the manufacturer's recommendation resulted in a 50\% seawater flush. During the acclimation period, we also fed the coral PhytoPlan ${ }^{\circledR}$ (marine phytoplankton for coral), ZoPlan ${ }^{\circledR}$ (zooplankton for coral), and MarineSnow ${ }^{\circledR}$ (biogenic aggregates) (Two Little Fishies $\odot$, Inc., Miami Gardens, FL, USA). Twelve colonies, each $\sim 25 \mathrm{~cm}^{2}$, were then fragmented into smaller $\sim 5 \mathrm{~cm}^{2}$ fragments containing at least three whole polyps (care was taken not to disrupt or destroy whole polyps) using a coral bandsaw equipped with a diamond blade (Gryphon Corporation, Sylmar, CA, USA). All "frags" (i.e., fragmented coral) were then placed into different holding tanks for an additional 7 days to help minimize stress associated with fragmentation. During the holding phase, tanks were monitored for coral health, algae growth, water quality, and chemistry. Water quality, chemistry, and feeding regimes described for the acclimation period were also implemented for the frags. Wild congener T. coccinea fragments (TCP) were obtained by aquarium suppliers from the Indo Pacific who have both import licenses and direct access to these species in their native environment. Rinsing and acclimation of these coral (TCP) followed the same protocols described above for coral we collected.

\subsection{Experimental Design and Analysis}

As two temperatures were used in this study, 24 small tanks were split into two groups with 6 tanks in each of four larger tanks. The larger tanks served as an insulating jacket to help maintain constant temperatures, while the individual tanks allowed for variation in $\mathrm{pH}$ and to decrease cross sample contamination. Tanks 1-12 were set in an insulating jacket of water and kept at $34 \pm 0.5^{\circ} \mathrm{C}$, while tanks $12-24$ were kept in a separate jacket and kept at $31 \pm 0.5^{\circ} \mathrm{C}$. Eheim $\odot$ Jager 100 watt Trutemp aquarium heaters accurate to $\pm 0.5^{\circ} \mathrm{C}$ were used to control water temperatures. Two heaters and water mixers per jacket maintained the desired temperatures, measured with calibrated alcohol thermometers every $4 \mathrm{~h}$ and with Onset $\odot$ TidbiT tiny temperature data loggers (accurate to $\pm 0.2^{\circ} \mathrm{C}$; Bourne, MA, USA). Salinity was maintained at $35 \mathrm{ppt}$ and measured every $4 \mathrm{~h}$ using a VWR Symphony SB70P $\mathrm{pH}$ meter (accurate to \pm 0.002 ). The $\mathrm{pH}$ was monitored once before, once during, and once following the experiment; $1 \mathrm{~N} \mathrm{HCl}$ and $1 \mathrm{M} \mathrm{NaOH}$ along with $0.5 \mathrm{M}$ HEPES were used to stabilize the $\mathrm{pHs}$ in this study. 
To help determine which $\mathrm{pH}$ would be best in comparing coral frags, we setup a LD50 (lethal dose) preliminary experiment using TC samples $(n=12)$ where $50 \%$ tissue loss occurred. TC samples were exposed to two temperatures $\left(31^{\circ} \mathrm{C}\right.$ and $\left.34^{\circ} \mathrm{C}\right)$ and a range of $\mathrm{pHs}(7.5,7.7,8,8.1)$ for $72 \mathrm{~h}$. Preliminary analysis consisted of photographs examining coral skeletons for tissue sloughing and/or bleaching. Over $72 \mathrm{~h}$, we observed no significant differences at any $\mathrm{pH}$ at $31^{\circ} \mathrm{C}$ (Figure 1). At $34{ }^{\circ} \mathrm{C}$, there were no significant differences between $\mathrm{pH} 7.5,7.7$, or 8.0 , but we did observe significant differences at $\mathrm{pH} 8.1$ at $34^{\circ} \mathrm{C}$ (Figure 1). Consequently, subsequent experiments consisted of two temperatures, $31^{\circ} \mathrm{C}$ and $34{ }^{\circ} \mathrm{C}$, and two pHs (7.5 and 8.1).

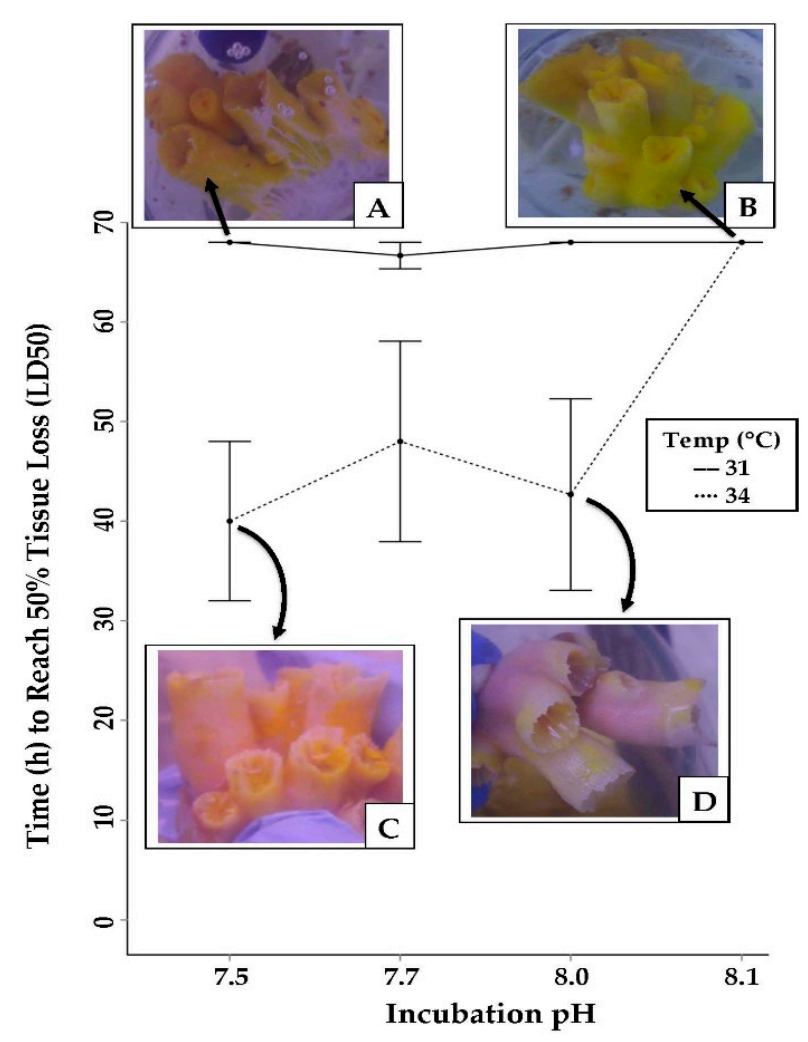

Figure 1. Preliminary analysis of the invasive Tubastraea coccinea (TC) to $\mathrm{pH}$ and temperature is presented. Temperature at $31^{\circ} \mathrm{C}$ is represented by the dark line; $34{ }^{\circ} \mathrm{C}$ is represented by the dotted line. Error bars indicate standard error. Panel (A) shows photograph of tissue appearance at $31{ }^{\circ} \mathrm{C}$, pH 7.5; (B) $31^{\circ} \mathrm{C}, \mathrm{pH} 8.0 ;$ (C) $34^{\circ} \mathrm{C}, \mathrm{pH} 7.5 ;$ (D) $34^{\circ} \mathrm{C}, \mathrm{pH} 8.0$.

\subsection{Tissue Loss Analysis}

Photographs of each fragment were taken every $4 \mathrm{~h}$ for analysis of tissue loss. Photographs were analyzed using Coral Point Count with Excel Extensions Software (CPCe) [54]. Tissue loss was determined by comparing the change in area between images [55-57].

\subsection{Western Blotting: Tissue Collection}

Monitoring heat shock protein 70 (HSP70) expression is a well-established technique when investigating coral stresses [58,59]. Despite the many HSP product types produced by coral, we focused on HSP70, as it has been shown to exist within the coral genome and not its symbiotic partner [60]. Here, western blot analysis for changes in the expression of heat shock protein 70 (HSP70) was performed on all coral samples. Coral samples were obtained using a hammer and chisel to separate polyps from the colony. A polyp was sampled from each tank $1 \mathrm{~h}$ after the beginning of the experiment to correspond to the peak expression of HSP 70 [51,61]. Samples were taken from each tank again at the end of 
$72 \mathrm{~h}$. If a coral specimen showed a $50 \%$ reduction in tissue, every replicate in its set was sampled immediately.

\subsubsection{Tissue Isolation}

After polyp segregation, tissue was homogenized in $20 \mathrm{~mL}$ of sterile seawater using a cold mortar and pestle. Samples were centrifuged at $2500 \times g$ for $2 \mathrm{~min}$ at $4{ }^{\circ} \mathrm{C}$ to remove skeletal material. Supernatant and tissue were collected and transferred to a new tube. Material was centrifuged at $7000 \times g$ for $10 \mathrm{~min}$ at $4{ }^{\circ} \mathrm{C}$. The supernatant was discarded and the pellet washed in $1 \mathrm{~mL}$ of sterilized seawater. The sample was centrifuged at $13,000 \times g$ for $2 \mathrm{~min}$, the supernatant removed, and the pellet flash frozen at $-80^{\circ} \mathrm{C}$.

\subsubsection{Protein Isolation}

Samples were removed from $-80{ }^{\circ} \mathrm{C}$ and thawed on ice. Cells were lysed in Lysis Buffer (20 mM Tris HCl pH7.5, $150 \mathrm{mM} \mathrm{NaCl}, 1 \mathrm{mM}$ EDTA, $1 \mathrm{mM}$ EGTA, 1\% triton, $2.5 \mathrm{mM}$ sodium pyrophosphate, $1 \mathrm{mM}$ beta-glycerophosphate, $1 \mathrm{mM}$ sodium vanadate, $1 \mu \mathrm{g} / \mathrm{mL}$ leupeptin (Cell Signaling Technology, Danvers, MA, USA)) containing $10 \mu \mathrm{g} \mathrm{mL}^{-1}$ aprotinin and $10 \mu \mathrm{g} \mathrm{mL}^{-1}$ PMSF. Cells were sonicated until ruptured. Lysates were clarified via centrifugation at $13,000 \times g$ for $10 \mathrm{~min}$ at $2{ }^{\circ} \mathrm{C}$. Equal protein concentrations were verified using the modified Ghosh method post lysis [62]. Loading buffer was then added to each sample (containing 3X DDT and 1X SDS, Cell Signaling Technologies, Danvers, MA, USA) and heated at $95{ }^{\circ} \mathrm{C}$ for $5 \mathrm{~min}$. Samples were either frozen at $-20{ }^{\circ} \mathrm{C}$ for later use or immediately loaded onto gels for electrophoresis.

\subsubsection{Gel Electrophoresis}

Electrophoresis and gel transfer were performed using a Mini-V 8.10 gel box system (Life Technology-Thermo Fisher Scientific, Waltham, MA, USA). Samples were run on 10\% SDS-polyacrylamide gels using Recombinant HSP70 protein (Enzo Life Science, Farmingdale, NY, USA) as a positive control. Post electrophoresis, proteins were transferred onto nitrocellulose membranes in buffer containing $25 \mathrm{mM}$ Tris-Cl, $192 \mathrm{mM}$ glycine, 20\% $v / v$ methanol, and $0.01 \%$ SDS, $\mathrm{pH}$ 8.5. Residual protein binding sites were blocked for $1 \mathrm{~h}$ in Tris Buffer Saline Tween-20 (TBST; $25 \mathrm{mM}$ Tris-Cl, pH 8.0, $150 \mathrm{mM} \mathrm{NaCl}, 0.5 \%$ Tween 20) containing $4 \%$ nonfat dry milk. Protein of interest (HSP70) was probed overnight $(\sim 18$ $24 \mathrm{~h}$ ) in TBST containing $2 \%$ nonfat dry milk and $1 \mu \mathrm{g} \mathrm{mL} \mathrm{g}^{-1}$ of antibody (HSP70 (LK-2) (Enzo Life Science, Farmingdale, NY, USA)). Following three 15-min washes in TBST, the nitrocellulose was probed with monoclonal-secondary anti-mouse antibody for $1 \mathrm{~h}$. Finally, the membrane was washed twice for $15 \mathrm{~min}$ in TBST, once for $15 \mathrm{~min}$ in Tris Buffered Saline (TBS), and developed using chemiluminescence detection. Changes in expression were analyzed using ImageJ software (National Institute of Health, Bethesda, MD, USA). Changes in density were normalized to a positive control (recombinant HSP70, Enzo Life Sciences, Farmingdale, NY, USA) and compared relative to a "time-0" control of HSP70 expression in a sample from Tubastraea coccinea at standard growth conditions.

\subsection{Statistical Analysis}

All data analysis was performed with R [63]. Graphical plotting was also performed on this platform utilizing the ggplot2 package. The response variable, percentage of live tissue, used for graphical outputs was not used for statistical analysis due to the inherent complexities and biases produced from percent change data. As a more robust statistical alternative, we used count data representing the number of hours required for a particular specimen to reach a live tissue percentage $\leq 50$ (LD50) as the response variable. The count data used for this study were negatively skewed, most likely due to the response variable being bounded to $0<\#$ hours $\leq 68$. Independent variables were considered as interval factors. We analyzed variance in the data, first using generalized linear models, $\operatorname{glm}()$, with the Poisson distribution and log link function. In the case of over-dispersion, a negative binomial model, glm.nb(), was used from the MASS package. Normality as well 
as the presence of influential outliers were determined using the visual diagnostic plots of glm.diag.plots() found in the boot package.

\section{Results}

\subsection{Preliminary Analysis}

To increase our resolution of invasive TC stress susceptibility, we examined TC at $\mathrm{pH}$ intervals, $7.5,7.7,8.0$, and 8.1. Fitting the data to a negative binomial glm with temperature and $\mathrm{pH}$ as independent variables and LD50 as the response variable, we observed temperature to have a significant impact on LD50 $(p<0.000)$. Increasing temperature from $31^{\circ} \mathrm{C}$ to $34^{\circ} \mathrm{C}$ again decreased the mean LD50 by a factor of 0.58 (Figure 1). A significant interaction between temperature and $\mathrm{pH}$ was also present in the model $(p=0.001)$.

\subsection{Tissue Loss Analysis}

To determine if invasive TC inhabiting the Gulf of Mexico are more resistant to stress than wild congeners from the Indo Pacific (TCP), we compared temperature and $\mathrm{pH}$ sensitivities over $72 \mathrm{~h}$ (Figure 2). Sampling every $4 \mathrm{~h}$ showed significant $(p<0.000)$ differences experienced for TC between temperatures $31^{\circ} \mathrm{C}$ and $34^{\circ} \mathrm{C}$ at $\mathrm{pH} 7.5$ and $\mathrm{pH} 8.1$ (Figure 2). However, fewer differences were observed for TCP (wild congeners) at $\mathrm{pH} 7.5$ at $31^{\circ} \mathrm{C}$ and $34{ }^{\circ} \mathrm{C}$ between hours 0 and 36 and hours 0 to 20 at pH 8.1 at $31{ }^{\circ} \mathrm{C}$ and $34{ }^{\circ} \mathrm{C}$. A full factorial negative binomial glm model ( $\mathrm{L} 50=$ Species $^{*}$ Temperature $\left.{ }^{*} \mathrm{pH}\right)$ was used to explain the variance in the data (theta $=31.0122$; AIC $=199.78$ ). Overall, the mean number of hours required to reach $50 \%$ tissue loss (LD50) for TCP was less than TC by a factor of $0.45(p<0.000)$. At the expected $\mathrm{pH}$ for tropical reef habitats ( $\mathrm{pH} 8.1)$, the LD50 decreased with increasing temperature (Figure 2). Consistent with this trend, increasing temperature from $31{ }^{\circ} \mathrm{C}$ to $34{ }^{\circ} \mathrm{C}$ was found to be a significant main effect $(p=0.004)$ decreasing the LD50 by a factor of 0.58 .

Comparing $\mathrm{pH}$ and temperature appears to have a greater negative effect on TCP than TC (Figure 2). At pH 7.1, TCP is significantly affected at temperatures $31^{\circ} \mathrm{C}$ and $34{ }^{\circ} \mathrm{C}$, whereas TC shows little response at $31^{\circ} \mathrm{C}$ and, at $34{ }^{\circ} \mathrm{C}$, does not respond until $12 \mathrm{~h}$ elapsed. Similarly, at $\mathrm{pH} 8.1$, TC has virtually no response at $34^{\circ} \mathrm{C}$ compared to TCP (Figure 2). At $34^{\circ} \mathrm{C}$ and $\mathrm{pH}$ 8.1, TCP responds quicker to stress, completely bleaching at $44 \mathrm{~h}$. Our statistical analysis also supports this finding, indicated by significant two- and three-way interaction terms $(p=0.01$ and $p=0.02)$.

\subsection{Western Blotting for HSP70}

Figure 3 displays changes in relative density of HSP70 expression at each experimental situation relative to a control of T. coccinea at standard growth conditions. At $31^{\circ} \mathrm{C}$ and $34^{\circ} \mathrm{C}$, there were no statistically significant differences between $\mathrm{pH} 7.5$ and $\mathrm{pH} 8.1$ for TC $(p=0.266)$; the general trend reflects a decrease in HSP70 concentrations between $\mathrm{pH} 8.1$ and $\mathrm{pH}$ 7.5. There are, however, significant differences of HSP70 expression at $31^{\circ} \mathrm{C}$ between $\mathrm{pH} 7.5$ and $\mathrm{pH} 8.1$ observed in TCP $(p=0.027)$ and between temperatures $31^{\circ} \mathrm{C}$ ( $\mathrm{pH} 7.5$ and $\mathrm{pH} 8.1)$ to $34^{\circ} \mathrm{C}(\mathrm{pH}$ 8.1) $(p=0.027)$. Similarly, significant differences exist between $31^{\circ} \mathrm{C}(\mathrm{pH} 8.1)$ and $34^{\circ} \mathrm{C}(\mathrm{pH} 7.5$ and $\mathrm{pH}$ 8.1) $(p=0.028)$. Although no statistically significant difference in HSP70 expression was observed for TCP at $34^{\circ} \mathrm{C}$ between $\mathrm{pH} 7.5$ and $\mathrm{pH} 8.1$, the general trend shows a greater concentration of HSP70 expression between temperatures irrespective of $\mathrm{pH}$. Comparing TC and TCP at each temperature and $\mathrm{pH}$, we did not observe any significant differences between HSP70 expression. 


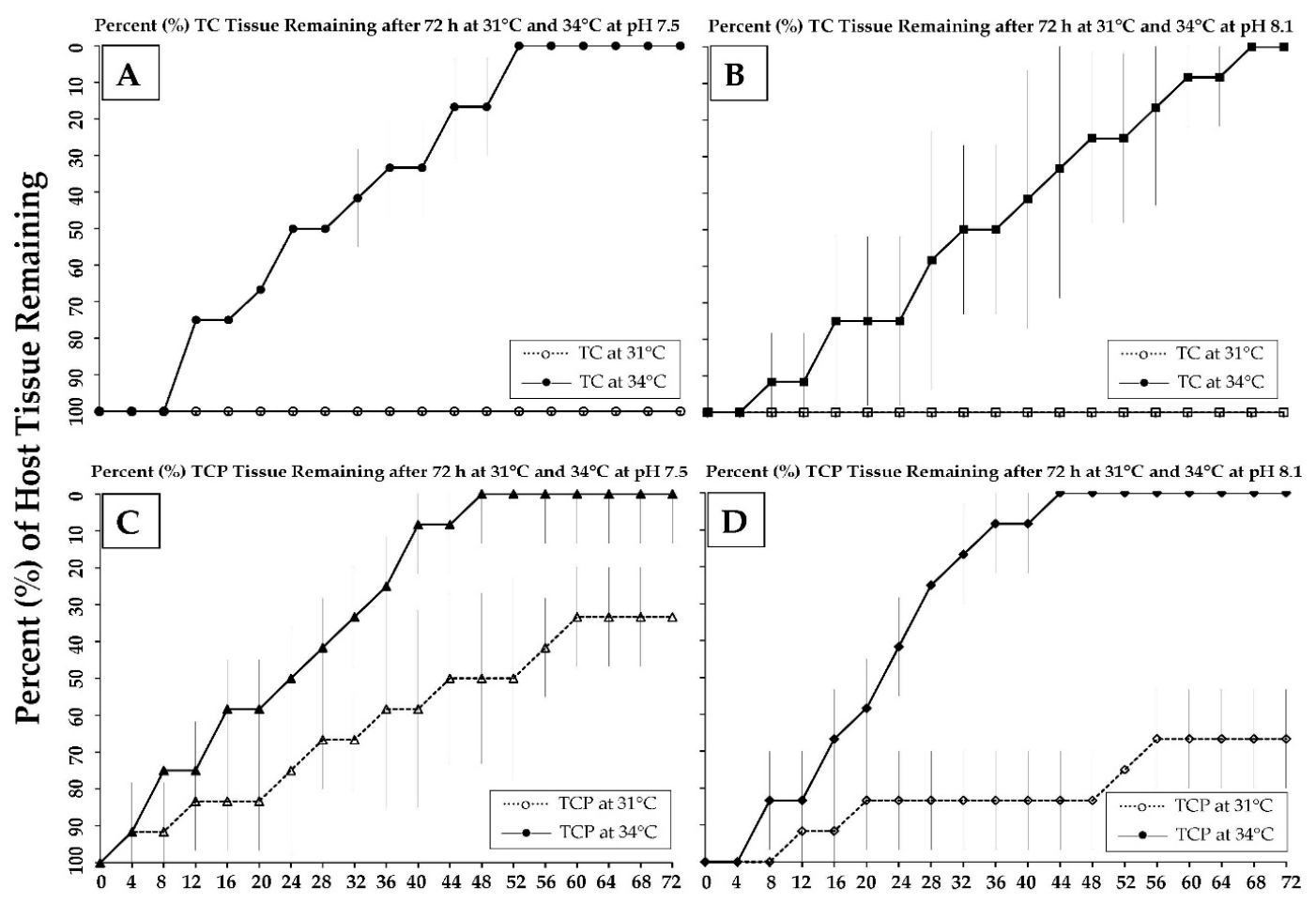

Time (h)

Figure 2. Coral bleaching as determined by the time (h) required to reach $50 \%$ tissue loss of invasive and wild Tubastraea coccinea to $\mathrm{pH}$ and temperature. "TC" represents the invasive T. coccinea, while "TCP" represents the wild Indo-Pacific congener. Percent (\%) of host tissue remaining on the y-axis is in 10\% divisions; time (h) on the x-axis ranges from 0-72 $\mathrm{h}$ in $4 \mathrm{~h}$ divisions. Error bars indicate 95\% CI. Some error bars are too small to observe. (A) Percent (\%) TC tissue remaining after $72 \mathrm{~h}$ at $31{ }^{\circ} \mathrm{C}$ and $34{ }^{\circ} \mathrm{C}$ at pH 7.5. (B) Percent (\%) TC tissue remaining after $72 \mathrm{~h}$ at $31^{\circ} \mathrm{C}$ and $34{ }^{\circ} \mathrm{C}$ at pH 8.1. (C) Percent (\%) TCP tissue remaining after $72 \mathrm{~h}$ at $31{ }^{\circ} \mathrm{C}$ and $34{ }^{\circ} \mathrm{C}$ at pH 7.5. (D) Percent (\%) TCP tissue remaining after $72 \mathrm{~h}$ at $31^{\circ} \mathrm{C}$ and $34^{\circ} \mathrm{C}$ at $\mathrm{pH} 8.1$.

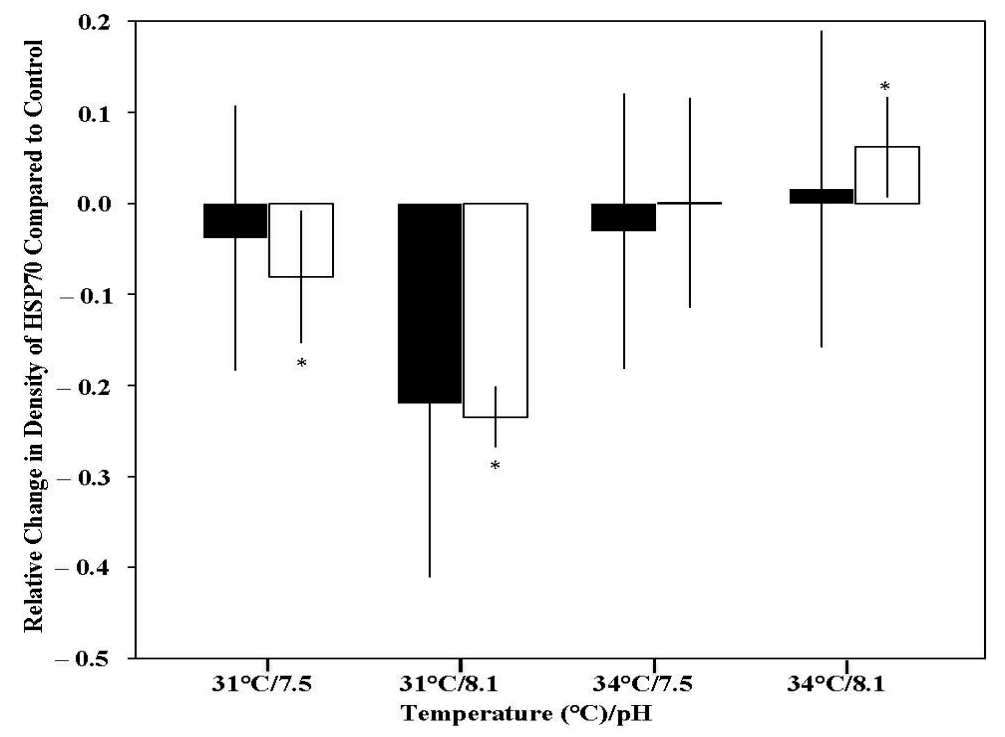

Figure 3. Relative change in density of expression of heat shock protein 70 (HSP70) from our 0-h control in Tubastraea coccinea. Treatment conditions are grouped by temperature $\left(31^{\circ} \mathrm{C}\right.$ or $\left.34^{\circ} \mathrm{C}\right)$ and $\mathrm{pH}$ (7.5 or 8.1). Samples were run in duplicate. Black bars represent TC (the invasive T. coccinea); white bars represent TCP (the wild Indo-Pacific congener). Error bars indicate $95 \%$ CI. Significant values comparing temperature and $\mathrm{pH}$ are as follows: ${ }^{*} \leq 0.05$. 


\section{Discussion}

Over the next few decades, the susceptibilities of individual species to the stresses of climate change, i.e., heat stress, ocean acidification, and calcification rates [64], will likely determine changes in ecosystems. Although invasive species have high potential to alter the ecosystems in which they reside, their impacts may exponentially increase if they are simultaneously able to resist the changing climate coupled to reduced predation and are less susceptible to disease. Based on our findings, TC has become a successful invader in the Western Atlantic probably due to its ability to withstand the effects of our changing climate as compared to its congener in the Indo-Pacific (TCP). Temperatures in the Western Atlantic are much cooler (season variation ranges from $-2{ }^{\circ} \mathrm{C}$ to $30^{\circ} \mathrm{C}$ ) [65] than those in the Gulf of Mexico $\left(20^{\circ} \mathrm{C}\right.$ to $28^{\circ} \mathrm{C}$ ) [66] or the Indo-Pacific, where annual temperatures remain above $28^{\circ} \mathrm{C}$ [67]. Hence, the congener (TCP) used to stable seasonal temperatures seems less capable of adapting to wide-fluctuating temperatures experienced by TC. The ability to withstand widely fluctuating temperatures may be the key to TC's success and may cause a shift in the local population where TC not only outcompetes other species but becomes the monodominant species. Our findings also suggest the potential for TC to remain a key species in future benthic communities of these areas.

As TC is an azooxanthellate coral, meaning it lacks the symbiotic algae common to many scleractinian coral; it does not experience the typical bleaching response, or expulsion of symbiotic algae, to elevated temperatures. However, previous studies have shown that azooxanthellate coral, such as Dendrophyllia sp., respond to increased temperatures with tissue loss and decreased calcification rates [64]. We therefore measured tissue loss as a measure of stress in response to increased temperatures and acidity in TC. Significant differences in tissue loss were observed between the response of endemic and invasive TC. Overall, TCP reached $50 \%$ tissue loss (LD50) faster than TC by a factor of 0.45 , indicating that invasive TC are more resistant to heat and $\mathrm{pH}$ stress than its endemic counterpart.

Increases in temperature were found to be a significant main effect $(p=0.004)$ on both species, while decreasing $\mathrm{pH}$ increased the tissue loss of only TCP at $31^{\circ} \mathrm{C}$, as decreasing the $\mathrm{pH}$ to 7.5 at ambient temperature had no significant effect on tissue loss in TC. Additionally, increasing $\mathrm{pH}$ on $\mathrm{TC}$ showed that temperature was not only significant but was the main effect in tissue loss ( $p<0.000$; as seen in Figure 2). As increased temperatures have been shown to decrease the calcification rate of an azooxanthellate coral, like zooxanthellate coral, temperatures are likely affecting a key part of the calcification process independent of light. Although a synergistic effect of temperature and increasing acidity was not apparent in either species, long-term monitoring of calcification rates of these coral could reflect decreases because of the known effects of temperature and decreased $\mathrm{pH}$ on coral calcification. Overall, however, TCP showed an increase in sensitivity to temperature and $\mathrm{pH}$ stress versus the invasive TC.

Although we did not observe a statistically significant effect of change in HSP70 expression for $\mathrm{TC}$ at $31{ }^{\circ} \mathrm{C}$ as $\mathrm{pH}$ changed from 8.1 to 7.5 , there was a significant change in HSP70 for TCP from $\mathrm{pH}$ 8.1 to 7.5. This suggests that the invasive species TC appears better adapted to $\mathrm{pH}$ at $31^{\circ} \mathrm{C}$ than TCP, which showed a significant reduction in expression of HSP70. Consequently, as ocean acidification continues to occur, the congener in the Indo Pacific (TCP) is likely to be more susceptible and less likely to survive. In general, this is cause for concern since HSP70 is typically released as a coping mechanism for species enduring unusually stressful climate changing conditions [68-70]. Prior to the industrial revolution, ocean $\mathrm{pH}$ was $\sim 8.2$ [71] but today is considered $\sim 8.1$ [72]. Whilst a decrease in $0.1 \mathrm{pH}$ units may seem infinitely small, that change in scale is not a 1:1 direct linear relationship and reflects a 30\% increase in acidity [73]. In our study, we observed a reduction in the amount of HSP70 released with increasing acidity at $31^{\circ} \mathrm{C}$. For the coral host, this represents lower temperature tolerance and increased susceptibility to bleaching, disease, immunity, and basic physiological conditioning (e.g., formation of the calcium carbonate skeleton). In the open ocean, such a decrease in acidity represents excess $\mathrm{H}^{+}$ ions binding to carbonate ions, resulting in fewer carbonate ions available for shells or 
skeletons [73]. At $34{ }^{\circ} \mathrm{C}$, decreases in HSP70 expression were similarly observed from $\mathrm{pH}$ 8.1 to 7.5 , representing stress. Hayes and King [51] similarly reported difficulties in the expression of HSP70. The rapid heat shock protein response of most organisms to stress is commonly regarded as a change in metabolic responses that confers a protective effect on the individual [74]. Indeed, many studies have determined that increases in HSP70 act as a method of organismal thermotolerance [75]. Although more research is needed to determine the downstream effects of HSP70 expression, our observed response in TC suggest it may play an important role in determining its success and overall dominance in stressful habitats where endemic species are less able to cope with increases in temperature coupled to decreases in alkalinity.

Our results also demonstrate the potential of TC to be more phenotypically plastic than TCP in their stress response and may help to explain TC's success in the Western Atlantic. Phenotypic plasticity is defined as a change in the phenotypic response of a genotype to a particular or suite of environmental changes [76]. Indeed, past research on a meta-analysis of invasive species has shown invasive species to demonstrate significantly higher phenotypic plasticity than non-invasives [77]. Although not measured here, if TC's phenotypic plasticity in response to climate stressors yields a higher-than-average fitness than other fixed genotypes (i.e., TCP), the TC phenotype may be considered better adaptive to climate change stressors and will likely continue to affect benthic substrates in the future. As such, the invasive azooxanthellate scleractinian coral T. coccinea (TC) is therefore a more robust species compared with Indo-Pacific congeners (TCP) (see Figure 2), with respect to the stressors and levels tested.

In this study, we show that the invasive species (TC) is more tolerant to changes in temperature and $\mathrm{pH}$ than their Indo-Pacific congeners (TCP); however, much more information is needed on their tolerance compared to native species in the Indo Pacific to fully determine their potential to dominate those reefs. Riul et al. [20] demonstrated T. coccinea and its widespread invasive potential through identification of large areas of climactically suitable habitat for invasion as well as its antagonistic behavior to the native coral, Mussismilia hispida, in Brazil. Future studies should be focused at determining similar models of T. coccinea invasion throughout its current invasive range as well as more in-depth models of its ability to persist climate change effects.

Author Contributions: Conceptualization, K.B.S., J.A.H. and B.H.-S.; methodology, K.B.S., J.A.H. and B.H.-S.; validation, K.B.S., J.A.H. and B.H.-S.; formal analysis K.B.S., J.A.H. and B.H.-S.; investigation, K.B.S., J.A.H., B.H.-S., J.D., K.C., S.K. and S.W.; resources, K.B.S.; data curation K.B.S., J.A.H. and B.H.-S.; writing—original draft preparation, K.B.S., J.A.H., B.H.-S., J.D., K.C., S.K. and S.W.; writingreview and editing, K.B.S., J.A.H. and B.H.-S.; visualization, K.B.S., J.A.H. and B.H.-S.; supervision, K.B.S., J.A.H. and B.H.-S.; project administration, K.B.S.; funding acquisition, K.B.S. All authors have read and agreed to the published version of the manuscript.

Funding: This project was funded by BOEM Environmental Studies Program to PWS, DAB, and KBS (GM-09-01-13) and NSF-REU: SURF (Summer Undergraduate Research Focus) to KBS and SC (Award\#1004903).

Acknowledgments: The authors wish to express their gratitude to the editor and the reviewers for their valuable comments and assistance in revising the manuscript.

Conflicts of Interest: The authors declare no conflict of interest.

\section{References}

1. Strychar, K.B.; Sammarco, P.W. Temperate Marine and Brackish Ecosystems. In Climate Change and Non-Infectious Fish Disorders (CCNFD); Woo Patrick, T.K., Iwama, G.K., Eds.; CAB International: Wallingford, UK, 2020; pp. 1-24, ISBN 978-1786393982.

2. Sammarco, P.W.; Strychar, K.B. Ecological and evolutionary considerations regarding corals in a rapidly changing environment. In The Cnidaria, Past, Present and Future; Goffredo, S., Dubinsky, Z., Eds.; Springer International Publishing: Cham, Switzerland, 2016; pp. 553-573, ISBN 978-3319313030. [CrossRef]

3. European Environment Agency (EEA). Climate Change and Water-Warmer Oceans, Flooding and Droughts. 2018. Available online: https:/ / www.eea.europa.eu/signals/signals-2018-content-list/articles/climate-change-and-water-2014 (accessed on 20 October 2021). 
4. Australian Academy of Science. More than Just Temperature-Climate Change and Ocean Acidification. 2021. Available online: https://www.science.org.au/curious/earth-environment/ocean-acidification. (accessed on 20 October 2021).

5. Skutnik, J.E.; Otieno, S.; Kean-Khoo, S.; Strychar, K.B. Examining the Effect of Heat Stress on Montastraea cavernosa (Linnaeus 1767) from a Mesophotic Coral Ecosystem (MCE). J. Water 2020, 12, 1303. [CrossRef]

6. Doney, S.C.; Ruckelshaus, M.; Duffy, J.E.; Barry, J.P.; Chan, F.; English, C.A.; Galindo, H.M.; Grebmeier, J.M.; Hollowed, A.B.; Knowlton, N.; et al. Climate change impacts on marine ecosystems. Annu. Rev. Mar. Sci. 2011, 4, 11-37. [CrossRef]

7. Allemand, D.; Osborn, D. Ocean acidification impacts on coral reefs: From sciences to solutions. Reg. Stud. Mar. Sci. 2019, 28, 100558. [CrossRef]

8. Doo, S.S.; Edmunds, P.J.; Carpenter, R.C. Ocean acidification effects on in situ coral reef metabolism. Sci. Rep. 2019, 9, 12067. [CrossRef]

9. Sammarco, P.W.; Porter, S.A.; Cairns, S.D. A new coral species introduced into the Atlantic Ocean-Tubastraea micranthus (Ehrenberg 1834) (Cnidaria, Anthozoa, Scleractinia): An invasive threat? Aquat. Invasions 2010, 5, 131-140. [CrossRef]

10. Sammarco, P.W.; Porter, S.A.; Sinclair, J.; Genazzio, M. Population expansion of a new invasive coral species, Tubastraea micranthus, in the northern Gulf of Mexico. Mar. Ecol. Prog. Ser. 2014, 495, 161-173. [CrossRef]

11. Sammarco, P.W.; Brazeau, D.A.; McKoin, M.; Strychar, K.B. Tubastraea micranthus: Comments on the population genetics of a new invasive coral in the Western Atlantic and a possible secondary invasion. J. Exp. Mar. Biol. Ecol. 2017, 490, 56-63. [CrossRef]

12. Capel, K.; Creed, J.C.; Kitahara, M.V. Invasive corals trigger seascape changes in the southwestern Atlantic. Bull. Mar. Sci. 2020, 96, 217-218. [CrossRef]

13. Figueroa, D.F.; McClure, A.; Figueroa, N.J.; Hicks, D.W. Hiding in plain sight: Invasive coral Tubastraea tagusensis (Scleractinia:Hexacorallia) in the Gulf of Mexico. Coral Reefs 2019, 38, 395-403. [CrossRef]

14. Vaughan, T.W.; Wells, J.W. (Eds.) Revision of the Suborders, Families, and Genera of the Scleractinia; Special Papers; Geological Society of America: Boulder, CO, USA, 1943; p. 44. [CrossRef]

15. Lesson, R.P. Voyage Autour du Monde sur La Coquille, Pendant les Annees 1822, 1823, 1824, et 1825, Zoology, 2: Zoophytes; A. Bertrand: Paris, France, 1829; pp. 1-151, (In French). Available online: https://gallica.bnf.fr/ark:/12148/bpt6k850915v (accessed on 16 December 2021).

16. Fenner, B.; Banks, K. Orange cup coral Tubastraea cocciena invades Florida and the Flower Garden Banks, Northwestern Gulf of Mexico. Coral Reefs 2004, 23, 505-507. [CrossRef]

17. de Paula, A.F.; Pires, D.; Creed, J. Reproductive strategies of two invasive sun corals (Tubastraea spp.) in the southwestern Atlantic. J. Mar. Biol. Assoc. UK 2014, 94, 481-492. [CrossRef]

18. Vermeij, M.J.A. A novel growth strategy allows Tubastraea coccinea to escape small-scale adverse conditions and start over again. Coral Reefs 2005, 24, 442. [CrossRef]

19. Sentoku, A.; Ezaki, Y. Regularity in budding mode and resultant growth morphology of the azooxanthellate colonial scleractinian Tubastraea coccinea. Coral Reefs 2012, 31, 67-74. [CrossRef]

20. Riul, P.; Targino, C.H.; Júnior, L.A.C.; Creed, J.C.; Horta, P.A.; Costa, G.C. Invasive potential of the coral Tubastraea coccinea in the southwest Atlantic. Mar. Ecol. Prog. Ser. 2013, 480, 73-81. [CrossRef]

21. Creed, J.C.; Fenner, D.; Sammarco, P.W.; Cairns, S.; Capel, K.; Junqueira, A.O.R.; Cruz, I.; Miranda, R.J.; Carlos-Junior, L.; Mantelatto, M.C.; et al. The invasion of the azooxanthellate coral Tubastraea (Scleractinia: Dendrophylliidae) throughout the world: History, pathways and vectors. Biol. Invasions 2016, 19, 283-308. [CrossRef]

22. Luz, B.L.P.; Domenico, M.D.; Migotto, A.E.; Kitahara, M.V. Life-history traits of Tubastraea coccinea: Reproduction, development, and larval competence. Ecol. Evol. 2020, 10, 6223-6238. [CrossRef] [PubMed]

23. Engelen, A.H.; Aires, T.; Vermeij, M.J.A.; Herndl, G.J.; Serrão, E.A.; Frade, P.R. Host differentiation and compartmentalization of microbial communities in the azooxanthellate cupcorals Tubastrea coccinea and Rhizopsammia goesi in the Caribbean. Front. Mar. Sci. 2018, 5, 391. [CrossRef]

24. Moreira, T.S.G.; Creed, J.C. Invasive, non-indigenous corals in a tropical rocky shore environment: No evidence for generalist predation. J. Exp. Mar. Biol. Ecol. 2012, 438, 7-13. [CrossRef]

25. Sammarco, P.W.; (Louisiana Universities Marine Consortium, Chauvin, LA, USA). Personal Communication, 2021.

26. Silva, A.G.; Lima, R.P.; Gomes, A.N.; Fleury, B.G.; Creed, J.C. Expansion of the invasive corals Tubastraea coccinea and Tubastraea tagusensis into the Tamoios Ecological Station Marine Protected Area, Brazil. Aquat. Invasion 2011, 6, S105-S110. [CrossRef]

27. Rodríguez-Villalobos, J.C.; Ayala-Bocos, A.; Hernández, L. Predation by Epidendrium billeeanum on Tubastrea coccinea: Use of the denuded skeleton for laying eggs. Coral Reefs 2016, 35, 271. [CrossRef]

28. Paz-García, D.A.; Aldana-Moreno, A.; Cabral-Tena, R.A.; Balart, E.F. High predation by the corallivore sea snail Jenneria pustulata in a high-latitude reef in the Gulf of California. Mar. Biodivers. Rec. 2012, 5, e94. [CrossRef]

29. Castro, C.B.; Pires, D. Brazilian coral reefs: What we already know and what is still missing. Bull. Mar. Sci. 2001, 69, 357-371.

30. Figueira de Paula, A.F.; Creed, J.C. Two species of the coral Tubastraea (Cnidaria, Scleractinia) in Brazil: A case study of accidental introduction. Bull. Mar. Sci. 2004, 74, 175-183.

31. Sampaio, C.L.S.; Miranda, R.J.; Maia-Nogueira, R.; José de Anchieta, C.C. NunesNew occurrences of the nonindigenous orange cup corals Tubastraea coccinea and T. tagusensis (Scleractinia: Dendrophylliidae) in Southwestern Atlantic. Check List 2012, 8 , 528-530. [CrossRef] 
32. Bianco, E.M.; de Oliveira, S.Q.; da Rosa Guimarães, T.; de Souza Pessoa, L.G.; Santos, M.E.A.; Dal-Pizzol, F.; Schenkel, E.P.; Reginatto, F.H. Tubastraea coccinea: A non-indigenous coral (Cnidaria, Scleractinia) collected at Arvoredo Island, South of Brazil with potential MRSA and VRE antimicrobial activity. Open J. Mar. Sci. 2016, 6, 334-340. [CrossRef]

33. Fenner, D. Biogeography of three Caribbean corals (Scleractinia) and the invasion of Tubastraea coccinea into the Gulf of Mexico. Bull. Mar. Scil. 2001, 69, 1175-1189.

34. Sammarco, P.W.; Porter, S.A.; Sinclair, J.; Genazzio, M. Depth distribution of a new invasive coral (Gulf of Mexico)—Tubastraea micranthus, comparisons with T. coccinea, and implications for control. Manag. Biol. Invasions 2013, 4, 291-303. [CrossRef]

35. Crivellaro, M.S.; Silveira, T.C.L.; Custódio, F.Y.; Battaglin, L.C.; Dechoum, M.d.S.; Fonseca, A.C.; Bárbara, S.; Riul, P.; Targino, C.H.; Junior, L.A.C.; et al. Fighting on the edge: Reproductive effort and population structure of the invasive coral Tubastraea coccinea in its southern Atlantic limit of distribution following control activities. Biol. Invasions 2020, 23, 811-823. [CrossRef]

36. Capel, K.C.C.; Toonen, R.J.; Rachid, C.T.C.C.; Creed, J.C.; Kitahara, M.V.; Forsman, Z.; Zilberberg, C. Clone wars: Asexual reproduction dominates in the invasive range of Tubastraea spp. (Anthozoa: Scleractinia) in the South-Atlantic Ocean. PeerJ 2017, e3873. [CrossRef]

37. Wellington, G.M.; Trench, R.K. Persistence and coexistence of a nonsymbiotic coral in open reef environments. Proc. Natl. Acad. Sci. USA 1984, 82, 2432-2436. [CrossRef] [PubMed]

38. Lages, B.G.; Fleury, B.G.; Menegola, C.; Creed, J.C. Change in tropical rocky shore communities due to an alien coral invasion. Mar. Ecol. Prog. Ser. 2011, 438, 85-96. [CrossRef]

39. Hoeksema, B.W.; Hiemstra, A.-F.; Vermeij, M.J.A. The rise of a native sun coral species on southern Caribbean coral reefs. Ecosphere 2019, 10, e02942. [CrossRef]

40. Sammarco, P.W.; Porter, S.A.; Genazzio, M.; Sinclair, J. Success in competition for space in two invasive coral species in the western Atlantic-Tubastraea micranthus and T. coccinea. PLoS ONE 2015, 10, e0144581. [CrossRef]

41. Kolian, S.R.; Sammarco, P.W. Densities of reef-associated fish and corals on offshore platforms in the Gulf of Mexico. Bull. Mar. Sci. 2019, 95, 393-407. [CrossRef]

42. Cairns, S. Stratigraphic distribution of Neogene azooxanthellate corals (Scleractinia, Stylasteridae). Bull. Am. Paleontol. 1999, 357, 109-118.

43. Capel, K.C.C.; Creed, J.; Kitahara, M.V.; Chen, C.A.; Zilberberg, C. Multiple introductions and secondary dispersion of Tubastraea spp. in the Southwestern Atlantic. Sci. Rep. 2019, 9, 13978. [CrossRef] [PubMed]

44. Zanotti, A.A.; Gregoracci, G.B.; Capel, K.C.C.; Kitahara, M.V. Microbiome of the Southwestern Atlantic invasive scleractinian coral, Tubastraea tagusensis. Anim. Microbiome 2020, 2, 29. [CrossRef]

45. Luz, B.L.P.; Zilberberg, C.; Flores, A.A.V.; Migotto, A.E.; Kitahara, M.V. A polyp from nothing: The extreme regeneration capacity of the Atlantic invasive sun corals Tubastraea coccinea and T. tagusensis (Anthozoa, Scleractinia). J. Exp. Mar. Biol. Ecol. 2018, 503, 60-65. [CrossRef]

46. de Mello Carpes, R.; de Assis Alves, M.; Creed, J.C.; da Silva, C.A.; Hamerski, L.; Garden, S.J.; Fleury, B.G.; Felzenszwalb, I. Mutagenic, genotoxic and cytotoxic studies of invasive corals Tubastraea coccinea and Tubastraea tagusensis. J. Appl. Toxicol. 2020, 40, 373-387. [CrossRef] [PubMed]

47. de Mello Carpes, R.; Fernandes, D.C.; Coelho, M.G.P.; Creed, J.C.; Fleury, B.G.; Garden, S.J.; Felzenszwalb, I. Anti-inflammatory potential of invasive sun corals (Scleractinia: Tubastraea spp.) from Brazil: Alternative use for management? J. Pharm. Pharmacol. 2020, 72, 633-647. [CrossRef]

48. Soares-Souza, G.B.; Amaral, D.; Batista, D.; Torres, A.Q.; Serra, A.C.S.; Uliano-Silva, M.; Leomil, L.; Reis, A.C.; Monteiro de Matos, E.; Calderon, E.; et al. The genomes of invasive coral Tubastraea spp. (Dendrophylliidae) as tool for the development of biotechnological solutions. bioRxiv 2020. [CrossRef]

49. LaJeunesse, T.C.; Parkinson, J.E.; Gabrielson, P.W.; Jeong, H.J.; Reimer, J.D.; Voolstra, C.R.; Santos, S.R. Systematic revision of Symbiodiniaceae highlights the antiquity and diversity of coral endosymbionts. Curr. Biol. 2018, 28, 2570-2580. [CrossRef]

50. Strychar, K.B.; Sammarco, P.W. Effects of heat stress on phytopigments of zooxanthellae (Symbiodinium spp.) symbiotic with the corals Acropora hyacinthus, Porites solida, and Favites complanata. Int. J. Biol. 2012, 4, 3-19. [CrossRef]

51. Hayes, R.L.; King, C.M. Induction of 70-kD heat shock protein in scleractinian corals by elevated temperature: Significance for coral bleaching. Mol. Mar. Bio. Biotechnol. 1995, 4, 36-42. [PubMed]

52. Agostini, S.; Harvey, B.P.; Wada, S.; Kon, K.; Milazzo, M.; Inaba, K.; Hall-Spencer, J.M. Ocean acidification drives community shifts towards simplified non-calcified habitats in a subtropical-temperate transition zone. Sci. Rep. 2018, 8, 11354. [CrossRef] [PubMed]

53. Mollica, N.R.; Guo, W.; Cohen, A.L.; Huang, K.-F.; Foster, G.L.; Donald, H.K.; Solow, A.R. Ocean acidification affects coral growth by reducing skeletal density. Proc. Natl. Acad. Sci. USA 2018, 115, 1754-1759. [CrossRef] [PubMed]

54. Kohler, K.E.; Gill, S.M. Coral Point Count with Excel extensions (CPCe): A Visual Basic program for the determination of coral and substrate coverage using random point count methodology. Comput. Geosci. 2006, 23, 1259-1269. [CrossRef]

55. Winters, G.; Holzman, R.; Blekhman, A.; Beer, S.; Loya, Y. Photographic assessment of coral chlorophyll contents: Implications for ecophysiological studies and coral monitoring. J. Exp. Mar. Biol. Ecol. 2009, 380, 25-35. [CrossRef]

56. Alvarez-Filip, L.; Estrada-Saldívar, N.; Pérez-Cervantes, E.; Molina-Hernández, A.; González-Barrios, F.J. A rapid spread of the stony coral tissue loss disease outbreak in the Mexican Caribbean. PeerJ 2019, 7, e8069. [CrossRef] 
57. Meiling, S.; Muller, E.M.; Smith, T.B.; Brandt, M.E. 3D Photogrammetry reveals dynamics of stony coral tissue loss disease (SCTLD) lesion progression across a thermal stress event. Front. Mar. Sci. 2020, 7, 597643. [CrossRef]

58. Louis, Y.D.; Bhagooli, R.; Seveso, D.; Maggioni, D.; Galli, P.; Vai, M.; Dyall, S.D. Local acclimatisation-driven differential gene and protein expression patterns of Hsp70 in Acropora muricata: Implications for coral tolerance to bleaching. Mol. Ecol. 2020, 29, 4382-4394. [CrossRef]

59. Seveso, D.; Arrigoni, R.; Montano, S.; Maggioni, D.; Orlandi, I.; Berumen, M.L.; Galli, P.; Vai, M. Investigating the heat shock protein response involved in coral bleaching across scleractinian species in the central Red Sea. Coral Reefs 2020, 39, 85-98. [CrossRef]

60. Tom, M.; Douek, J.; Yankelevich, I.; Bosch, T.C.; Rinkevich, B. Molecular characterization of the first heat shock protein 70 from a reef coral. Biochem. Biophys. Res. Commun. 1999, 262, 103-108. [CrossRef] [PubMed]

61. Yetsko, K.L. Estimating the Heritability of Thermal Tolerance in Acropora cervicornis and the Physiological Basis of Adaptation that Correlates to Survival at Elevated Temperatures. Master's Thesis, University of North Florida, Jacksonville, FL, USA, 2018.

62. Ghosh, S.; Gepstein, S.; Heikkila, J.J.; Dumbroff, B.G. Use of a scanning densitometer or an ELISA plate reader for measurement of nanogram amounts of protein in crude extracts from biological tissue. Anal. Biochem. 1988, 169, 227-233. [CrossRef]

63. R Core Team. R: A Language and Environment for Statistical Computing; R Foundation for Statistical Computing: Vienna, Austria, 2020. Available online: https:/ /www.R-project.org/ (accessed on 16 December 2021).

64. Marshall, A.T.; Clode, P. Calcification rate and the effect of temperature in a zooxanthellate and azooxanthellate scleractinian reef coral. Coral Reefs 2004, 23, 218-224. [CrossRef]

65. US Navy. Atlantic Ocean Facts. Archived from the Original on 2 March 2001. Available online: http:/ / oceanographer.navy.mil/ atlantic.html (accessed on 15 November 2021).

66. Anonymous. Temperature of the Water of the Gulf of Mexico. 2021. Available online: https://www.seatemperatu.re/seas-andoceans / gulf-of-mexico/ (accessed on 15 November 2021).

67. Kaur, A.; Kumar, P.; Weller, E.; Young, I.R. Positive relationship between seasonal Indo-Pacific Ocean wave power and SST. Sci. Rep. 2021, 11, 17419. [CrossRef]

68. Hang, H.; Fox, M.H. Low pH suppresses synthesis of heat-shock proteins and thermotolerance. Radiat. Res. 1994, 140, 24-30. Available online: http:/ / www.jstor.org/stable/3578564 (accessed on 16 December 2021). [CrossRef] [PubMed]

69. Gullian, K.M.; Terrats, P.M. Effect of $\mathrm{pH}$ on temperature controlled degradation of reactive oxygen species, heat shock protein expression, and mucosal immunity in the sea cucumber Isostichopus badionotus. PLoS ONE 2017, 12, e0175812. [CrossRef]

70. Cornwall, C.E.; Comeau, S.; Kornder, N.A.; Perry, C.T.; van Hooidonk, R.; DeCarlo, T.M.; Pratchett, M.S.; Anderson, K.D.; Browne, N.; Carpenter, R.; et al. Global declines in coral reef calcium carbonate production under ocean acidification and warming. Proc. Natl. Acad. Sci. USA 2021, 118, e2015265118. [CrossRef] [PubMed]

71. Feely, R.; Doney, S.C.; Cooley, S.R. Ocean acidification: Present conditions and future changes in a high-CO 2 world. Oceanography 2009, 22, 36-47. [CrossRef]

72. Garcia-Soto, C.; Cheng, L.; Caesar, L.; Schmidtko, S.; Jewett, E.B.; Cheripka, A.; Rigor, I.; Caballero, A.; Chiba, S.; Báez, J.C.; et al. An overview of ocean climate change indicators: Sea surface temperature, ocean heat content, ocean $\mathrm{pH}$, dissolved oxygen concentration, arctic sea ice extent, thickness and volume, sea level and strength of the AMOC (Atlantic Meridional Overturning Circulation). Front. Mar. Sci. 2021, 8, 642372. [CrossRef]

73. Winner, C. Small drop in pH Means Big Change in Acidity. Oceans: The Socioeconomic Costs of Ocean Acidification. 2010. Available online: https:/ / www.whoi.edu/oceanus/feature/small-drop-in-ph-means-big-change-in-acidity (accessed on 20 October 2021).

74. Hendrick, J.P.; Hartl, F.U. Molecular chaperone functions of heat-shock proteins. Annu. Rev. Biochem. 1993, 62, 349-384. [CrossRef] [PubMed]

75. Brown, B.E.; Downs, C.A.; Dunne, R.P.; Gibb, S.W. Exploring the basis of thermotolerance in the reef coral Goniastrea aspera. Mar. Ecol. Prog. Ser. 2002, 242, 119-129. [CrossRef]

76. Bradshaw, A.D. Evolutionary significance of phenotypic plasticity in plants. Adv. Genet. 1965, 13, 115-155. [CrossRef]

77. Davidson, A.M.; Jennions, M.; Nicotra, A.B. Do invasive species show higher phenotypic plasticity than native species and, if so, is it adaptive? A meta-analysis. Ecol. Lett. 2011, 14, 419-431. [CrossRef] [PubMed] 